\title{
Water vapor increase in the lower stratosphere of the Northern Hemisphere due to the Asian monsoon anticyclone observed during the TACTS/ESMVal campaigns
}

\author{
Christian Rolf $^{1}$, Bärbel Vogel ${ }^{1}$, Peter Hoor ${ }^{2}$, Armin Afchine ${ }^{1}$, Gebhard Günther ${ }^{1}$, Martina Krämer ${ }^{1}$, Rolf Müller ${ }^{1}$, \\ Stefan Müller ${ }^{2,3}$, Nicole Spelten ${ }^{1}$, and Martin Riese ${ }^{1}$ \\ ${ }^{1}$ Institute for Energy and Climate Research (IEK-7), Forschungszentrum Jülich GmbH, Jülich, Germany \\ ${ }^{2}$ Institute for Atmospheric Physics, Johannes Gutenberg University, Mainz, Germany \\ ${ }^{3}$ now at: Enviscope GmbH, 60489 Frankfurt, Germany
}

Correspondence: Christian Rolf (c.rolf@fz-juelich.de)

Received: 12 September 2017 - Revised: 20 October 2017 - Accepted: 9 January 2018 - Published: 1 March 2018

\begin{abstract}
The impact of air masses originating in Asia and influenced by the Asian monsoon anticyclone on the Northern Hemisphere stratosphere is investigated based on in situ measurements. A statistically significant increase in water vapor $\left(\mathrm{H}_{2} \mathrm{O}\right)$ of about $0.5 \mathrm{ppmv}(11 \%)$ and methane $\left(\mathrm{CH}_{4}\right)$ of up to $20 \mathrm{ppbv}(1.2 \%)$ in the extratropical stratosphere above a potential temperature of $380 \mathrm{~K}$ was detected between August and September 2012 during the HALO aircraft missions Transport and Composition in the UT/LMS (TACTS) and Earth System Model Validation (ESMVal). We investigate the origin of the increased water vapor and methane using the three-dimensional Chemical Lagrangian Model of the Stratosphere (CLaMS). We assign the source of the moist air masses in the Asian region (northern and southern India, eastern China, southeast Asia, and the tropical Pacific) based on tracers of air mass origin used in CLaMS. The water vapor increase is correlated with an increase of the simulated Asian monsoon air mass contribution from about $10 \%$ in August to about $20 \%$ in September, which corresponds to a doubling of the influence from the Asian monsoon region. Additionally, back trajectories starting at the aircraft flight paths are used to differentiate transport from the Asian monsoon anticyclone and other source regions by calculating the Lagrangian cold point (LCP). The geographic location of the LCPs, which indicates the region where the set point of water vapor mixing ratio along these trajectories occurs, can be predominantly attributed to the Asian monsoon region.
\end{abstract}

\section{Introduction}

Radiatively active trace gases, such as water vapor and methane, play a key role in determining the radiative balance in the upper troposphere and lower stratosphere (UTLS) and thus have an impact on the surface climate of the Earth (Forster and Shine, 2002; Riese et al., 2012). In particular, only small increases/decreases of stratospheric water vapor on the order of $10 \%$ have a significant influence on the radiative forcing and thus constitute warming/cooling potential for global surface temperature on the order of 25-30\% (Solomon et al., 2010). In this paper, we focus on transport pathways and exchange processes between troposphere and stratosphere to better understand the variability of water vapor and methane in this climatically sensitive region of the atmosphere.

In general, frozen, dry air masses with a low amount of water vapor enter the stratosphere in the tropical tropopause layer (TTL) and are transported vertically via the BrewerDobson circulation (BDC) deep into the stratosphere and quasi-horizontally into the extratropical lower stratosphere (Ex-LS; e.g., Gettelman et al., 2011) . Thus, the air in the Ex-LS constitutes a mixture of young air masses originating from quasi-horizontal transport out of the TTL and old stratospheric air in the downwelling branch of the BDC (e.g., Bönisch et al., 2009; Ploeger et al., 2013; Vogel et al., 2016). As a rule, increasing inflow of tropospheric air masses from the tropics in combination with higher temperatures in the tropopause region causes a moistening of the Ex-LS in summer compared to winter months (e.g., Hoor et al., 2005; 
Krebsbach et al., 2006; Ploeger et al., 2013; Randel and Jensen, 2013; Zahn et al., 2014). This moistening is partly due to the Asian summer monsoon which facilitates the transport of water vapor into the northern lowermost stratosphere (e.g., Dethof et al., 1999; Randel and Jensen, 2013). The monsoon system is linked to rapid vertical transport of surface air from India and east Asia in the summer months (July to October). These young and moist tropospheric air masses from close to the surface are to some degree horizontally confined in the upper troposphere by the Asian monsoon anticyclone (AMA). The edge of the AMA constitutes a transport barrier characterized by a potential vorticity (PV) gradient (Ploeger et al., 2015). The transport barrier is rather leaky due to the strong dynamic variability of the anticyclone consisting of meridional displacements, splits, and eddy-shedding events (e.g., Vogel et al., 2014, 2015; Ungermann et al., 2016). However, this confinement with reduced cross-gradient transport is responsible for an enrichment of tropospheric constituents and higher amounts of water vapor and methane in the upper troposphere (e.g., Park et al., 2004, 2007; Schuck et al., 2010; Patra et al., 2011; Baker et al., 2012; Bian et al., 2012; Pan et al., 2016; Santee et al., 2017). A horizontal transport pathway out of the anticyclone is directed westwards into the tropical tropopause layer (TTL; Popovic and Plumb, 2001; Randel and Park, 2006). A second pathway of moist and polluted air masses exists, where air from the AMA is transported eastwards along the subtropical jet and subsequently into the northern lower stratosphere via eddy shedding followed by tropopause crossing (e.g., Dethof et al., 1999; Hsu and Plumb, 2000; Vogel et al., 2014, 2016). These frequently occurring eddy-shedding events triggered by Rossby wave activity flood the northern lower stratosphere with tropospheric air masses from the Asian subcontinent and cause a moistening of the Ex-LS (e.g., Müller et al., 2016; Vogel et al., 2014, 2016). In addition, Aura Microwave Limb Sounder (MLS) satellite observations showed that the Asian monsoon is hydrating the northern stratosphere (Uma et al., 2014).

From an observational point of view, the influence of the Asian monsoon on the Ex-LS is mostly analyzed based on satellite limb sounder measurements, which have only limited vertical resolution, typically larger than $1-2 \mathrm{~km}$ in the lowermost stratosphere (e.g., Hegglin et al., 2013; Santee et al., 2017). Especially in the tropopause region, this coarse resolution can smooth the strong vertical gradient of water vapor at the tropopause and may lead to an over- or underestimation of the water vapor concentration in the lower stratosphere. Here, we present high-resolution and precise in situ water vapor and methane measurements in the northern lower stratosphere performed in August and September 2012. We investigate the changes of these trace gases during the observational time period and attribute them to transport from the Asian monsoon region by using Lagrangian back-trajectory analysis in combination with artificial tracers of air mass origin.

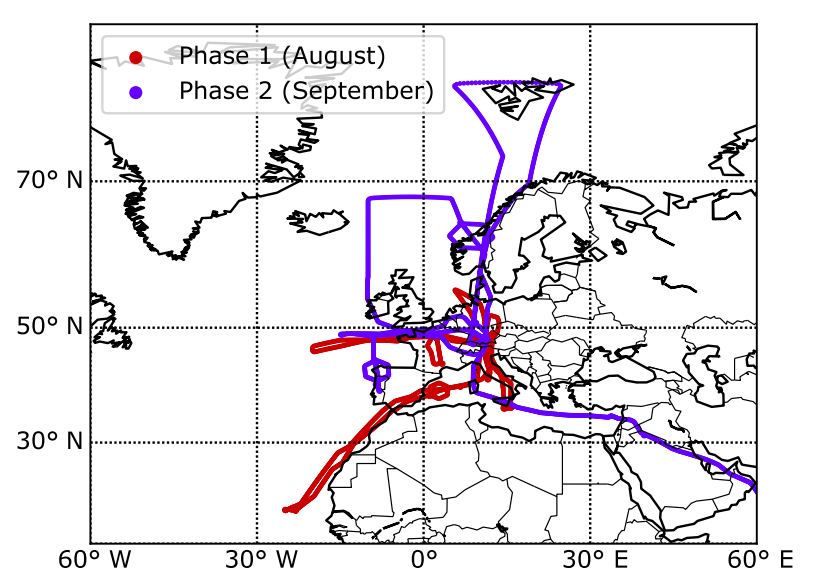

Figure 1. Flight paths of all analyzed flights during the TACTS and ESMVal campaigns. The flight paths of phase 1 and phase 2 are plotted in red and blue, respectively.

\section{Methods and instruments}

This study is based on the data collected during the two aircraft campaigns Transport and Composition in the UT/LMS (TACTS) and Earth System Model Validation (ESMVal). These campaigns were conducted between August and October 2012 mainly in the Northern Hemisphere in the region from the Cabo Verde islands to the Arctic and over Europe and the Atlantic Ocean. The data are split into two time periods. These two periods, referred to as phase 1 and phase 2 hereafter, cover the time period from 28 August to 5 September and from 18 to 26 September 2012, respectively. Figure 1 shows the map of all considered flight paths and the respective phases they are attributed to. Vogel et al. (2016) provided grounds for this selection, showing that the strongest transport of young air masses from the AMA into the Ex-LS occurred in the period between August and the end of September, mainly associated with a pronounced eddyshedding event on 20 September 2012 (Vogel et al., 2014). Thus, the selection of these dates reveals a clear difference in the water vapor distribution in the Ex-LS, as shown in Sect. 3.1. More information about the data coverage can be found in Müller et al. (2016). The separation allows for the investigation of the temporal evolution of the trace gas composition of the Ex-LS between the two phases. In the following, the water vapor and methane instruments aboard the HALO aircraft are briefly described. In addition, we used CLaMS (Chemical Lagrangian Model for the Stratosphere; McKenna et al., 2002b) results interpolated onto the flight path, and also CLaMS backward-trajectory calculations from the measurement locations for identification of the air mass origin as described further below. 


\subsection{Water vapor measurements}

The water vapor data used in this study were measured using the Fast In situ Stratospheric Hygrometer (FISH) instrument. The measurement technique is based on Lyman- $\alpha$ photofragment fluorescence and is suitable for measuring water vapor in the range of 1 to 1000 ppmv (Zöger et al., 1999). FISH is a well-established closed-path hygrometer with a long history in aircraft measurements and instrument intercomparisons (Meyer et al., 2015). Calibrations are performed during the campaigns with a MBW DP30 frost point hygrometer achieving accuracy of $6 \% \pm 0.4 \mathrm{ppmv}$ at a time resolution of $1 \mathrm{~Hz}$ during TACTS/ESMVal.

\subsection{Methane measurements}

The methane data are obtained using the TRacer In situ QCL and HydrOgen Peroxide monitor (TRIHOP) instrument. The measurement technique is based on infrared absorption spectroscopy with a three-channel quantum cascade laser spectrometer capable of measuring $\mathrm{CO}, \mathrm{CO}_{2}, \mathrm{~N}_{2} \mathrm{O}$, and $\mathrm{CH}_{4}$. In situ calibration against a secondary standard traceable to the NOAA scale was applied during the campaign. TRIHOP methane data are available every $8 \mathrm{~s}$ with an integration time of $1.5 \mathrm{~s}$, precision of $9.5 \mathrm{ppbv}(2 \sigma)$, and an uncertainty of $13.5 \mathrm{ppbv}$ relative to the standard. For more details, see Müller et al. (2016).

\subsection{CLaMS simulations with artificial air mass origin tracers}

In this study, we used the three-dimensional chemistry transport model CLaMS (McKenna et al., 2002b, a; Pommrich et al., 2014, and references therein) according to the setup described in (Vogel et al., 2015). The air parcels within the CLaMS model are represented by an ensemble of air parcels on a time-dependent irregular grid which are transported in a Lagrangian way using trajectories including a physical representation of mixing (Konopka et al., 2004, 2010). This allows for tracer gradients to be represented in a particularly accurate manner in CLaMS model simulations, making the model simulations well suited for investigating transport and troposphere-stratosphere interaction (e.g., Konopka et al., 2010; Pommrich et al., 2014; Vogel et al., 2015, 2016).

The CLaMS simulation used here covers the time period from 1 May to 31 October 2012, and captures the Asian monsoon season in 2012. The simulation is driven by the meteorological fields of the European Reanalysis Interim (ERAInterim) data set (Dee et al., 2011) from the European Centre for Medium-range Weather Forecasts (ECMWF) and covers the atmosphere from the surface up to $900 \mathrm{~K}$ potential temperature $(\approx 37 \mathrm{~km}$ altitude) with a vertical resolution of $400 \mathrm{~m}$ around the tropopause. In the simulation, "emission tracers" are released in the boundary layer $(\approx 2-3 \mathrm{~km}$ above surface) which globally marks all regions of the Earth's sur-
Table 1. Latitude and longitude range of artificial boundary layer sources in the CLaMS model, which are used to define the "Asian monsoon surface tracer" (MON).

\begin{tabular}{lll}
\hline Emission tracer & Latitude & Longitude \\
\hline Northern India (NIN) & $20-40^{\circ} \mathrm{N}$ & $55-90^{\circ} \mathrm{E}$ \\
Southern India (SIN) & $0-20^{\circ} \mathrm{N}$ & $55-90^{\circ} \mathrm{E}$ \\
Eastern China (ECH) & $20-40^{\circ} \mathrm{N}$ & $90-125^{\circ} \mathrm{E}$ \\
Southeast Asia (SEA) & $12-20^{\circ} \mathrm{N}$ & $90-155^{\circ} \mathrm{E}$ \\
Tropical Pacific Ocean & $20^{\circ} \mathrm{S}-20^{\circ} \mathrm{N}$ & $55^{\circ} \mathrm{E}-80^{\circ} \mathrm{W}$ \\
(TPO) & & \\
\hline
\end{tabular}

face. These different artificial tracers are freshly emitted every $24 \mathrm{~h}$ in the boundary layer and their concentration in the atmosphere represents the air mass contributions from the respective source regions. For more details, see Vogel et al. (2015, 2016).

(Vogel et al., 2015) showed that the emission tracers for India and eastern China are correlated with high values of potential vorticity (PV) and Aura MLS (Livesey et al., 2011) satellite measurements of $\mathrm{O}_{3}$ and $\mathrm{CO}$. Thus, they can be used as proxies for the location and shape of the AMA and allow for transport studies of air masses from the AMA into the northern extratropical lower stratosphere. In addition, the emission tracers from southeast Asia and the Pacific Ocean contribute to the air mass composition of the outer edge of the AMA (Vogel et al., 2015, 2016). Thus, to study the transport of air masses affected by the Asian monsoon, the most important emission regions are India/China, southeast Asia, and the tropical Pacific Ocean. The sum of all these model boundary layer tracers is referred to as "Asian monsoon surface tracer" (MON; see Table 1). This tracer marks young air masses (younger than 5 months) that are confined during summer in the AMA and air masses from southeast Asia and the tropical Pacific Ocean influenced by the large-scale flow around the anticyclone in the UTLS. MON tracer preferentially accumulates with contributions up to $40 \%$ in and around the AMA and is clearly separated from the tropics and regions outside of the monsoon circulation with a contribution of around $10 \%$ (see Fig. 5 in Vogel et al., 2016). All other source regions can be neglected, since it was shown in Vogel et al. (2016) that these regions did not make a significant contribution to the transport of young tropospheric air masses into the lower stratosphere in summer and autumn 2012 .

\subsection{Air mass trajectory calculations}

In contrast to the three-dimensional CLaMS simulations, pure trajectory calculations do not account for mixing. However, the position of an air parcel and the changes in temperature along the trajectory can be tracked with sufficient accuracy over several days or even weeks (e.g., Vogel et al., 2014; Rolf et al., 2015). The air mass trajectories are calculated by 
means of the CLaMS trajectory module for the last 50 days and for every $10 \mathrm{~s}$ from the location of the flight path using ERA-Interim data (Dee et al., 2011). The trajectories are based on the horizontal wind fields and diabatic heating rates with a resolution of $1^{\circ} \times 1^{\circ}$ with 60 vertical levels from the surface up to $0.1 \mathrm{hPa}$. Additional parameters, such as temperature, pressure, and potential vorticity (PV) are interpolated from the ERA-Interim data onto the trajectories. In addition, the local distance to the thermal tropopause (WMO) is calculated for each trajectory time step and added to the trajectory data (e.g., Krebsbach et al., 2006). The water vapor saturation mixing ratio with respect to ice (hereafter saturation mixing ratio) along the trajectories is calculated based on the actual trajectory temperature. The Lagrangian cold point (LCP) is defined by the minimum of the temperature along the trajectory and thus the minimum saturation mixing ratio. With these parameters, pure stratospheric trajectories can be separated from trajectories with a tropospheric origin within the last 50 days by comparing the distance to the tropopause before and after the LCP. All trajectories with a negative distance to the thermal tropopause before the LCP and a negative distance afterwards passed the tropopause from the troposphere into the stratosphere and represent air masses which originate in the troposphere.

Convection is the main process that transports air masses vertically from the ground into the upper troposphere in the Asian monsoon region. In the model simulations shown here, vertical transport is taken into account as represented in ERA-Interim including latent heat related transport (for pressure less than $\approx 300 \mathrm{hPa}$ ). Thus, the very small-scale rapid uplift in convective cores cannot included in CLaMS simulations and trajectory calculation. However, for the questions addressed here, which are concerned with large-scale uplift in the monsoon, these small-scale features might be less relevant. In particular, previous studies using 3-D CLaMS simulations or trajectory calculations (e.g., Ploeger et al., 2015; Pommrich et al., 2014; Vogel et al., 2014, 2016; Müller et al., 2016; Ungermann et al., 2016), in comparison with satellite or in situ measurements, show that ERA-Interim data are well suited for studying transport processes in the vicinity of the AMA and for CLaMS to reproduced every small-scale feature in the measurements.

\section{Results}

The main purpose of this study is to corroborate the hypothesis that air masses from Asia and the tropical Pacific affected by the AMA are the main source of the moistening found in the Ex-LS in late summer and fall in the Northern Hemisphere, at least for the campaign period. Firstly, we present in situ water vapor measurements of the two phases (August and September) and support the hypothesis based on water vapor-methane correlations. Secondly, we combine the measurements with CLaMS model results and the 50- day backward-trajectory analysis to ultimately confirm the hypothesis.

\subsection{Moistening the Ex-LS}

Water vapor is strongly coupled to temperature. The thermal tropopause in the sub-tropics and mid-latitudes is found to be a good indicator for marking the critical level of the temperature gradient and sharp relative humidity change, as shown by Pan and Munchak (2011), and thus separates the moist tropospheric regime from the dry stratospheric regime. In addition, isentropic transport is found to be the main pathway from the AMA into the Ex-LS (Vogel et al., 2016). Therefore, we choose the distance to the local thermal tropopause as the vertical coordinate in units of potential temperature. In Fig. 2a and b, we display the mean water vapor distributions of both phases (phase 1 and phase 2) along the PVbased equivalent latitude (EqLat). The use of EqLat allows us to combine observations performed at different times and locations by neglecting short-term dynamical variability (e.g., planetary wave activity at the sub-tropical jet). High water vapor mixing ratios (>10 ppmv), representing moist tropospheric air, can be found below and up to $20 \mathrm{~K}$ above the thermal tropopause during both phases. Drier air masses down to the stratospheric background level of 4-5 ppmv are observed 30 to $90 \mathrm{~K}$ above the thermal tropopause. In phase 1 , the drier air masses are observed closer to the thermal tropopause, while in phase 2 such dry air masses are found at potential temperatures $10 \mathrm{~K}$ higher. Both distributions have similar vertical and horizontal extents, and thus the difference between the phases reveals local changes in water vapor mixing ratios over the time period (see Fig. 2c). Air masses with $\mathrm{PV}<8 \mathrm{PVU}$ reveal large variability between phase 2 and phase 1 , most likely due to the local variability of the thermal tropopause not captured by the ECMWF data and planetary wave activity which distort the location of the sub-tropical jet core. Kunz et al. (2015) showed that the climatological transport barrier between tropospheric and stratospheric air masses is located at PV values of 7-8 PVU between June and November in the Northern Hemisphere. Thus, we will focus on air masses with $\mathrm{PV}>8 \mathrm{PVU}$ in the following analysis, since they are not affected by small-scale mixing processes directly at the tropopause.

All the air masses with PV values larger than 8 PVU show a distinct $5-10 \%$ increase of water vapor in phase 2 compared to phase 1 . The occurrence of these air masses ranges from 40 to $75^{\circ} \mathrm{N}$ in equivalent latitude horizontally and corresponds to potential temperatures larger than $380 \mathrm{~K}$. The frequency distributions of the water vapor mixing ratios with $\mathrm{PV}$ values larger than $8 \mathrm{PVU}$ allow us to quantify the strength of moistening between the phases (see Fig. 2d). The frequency distribution of phase 1 is very compact with a mean water vapor mixing ratio of $4.5 \mathrm{ppmv}$, while the distribution of phase 2 is shifted to higher water vapor mixing ratios with a mean value of 5 ppmv and shows a tail towards higher water 

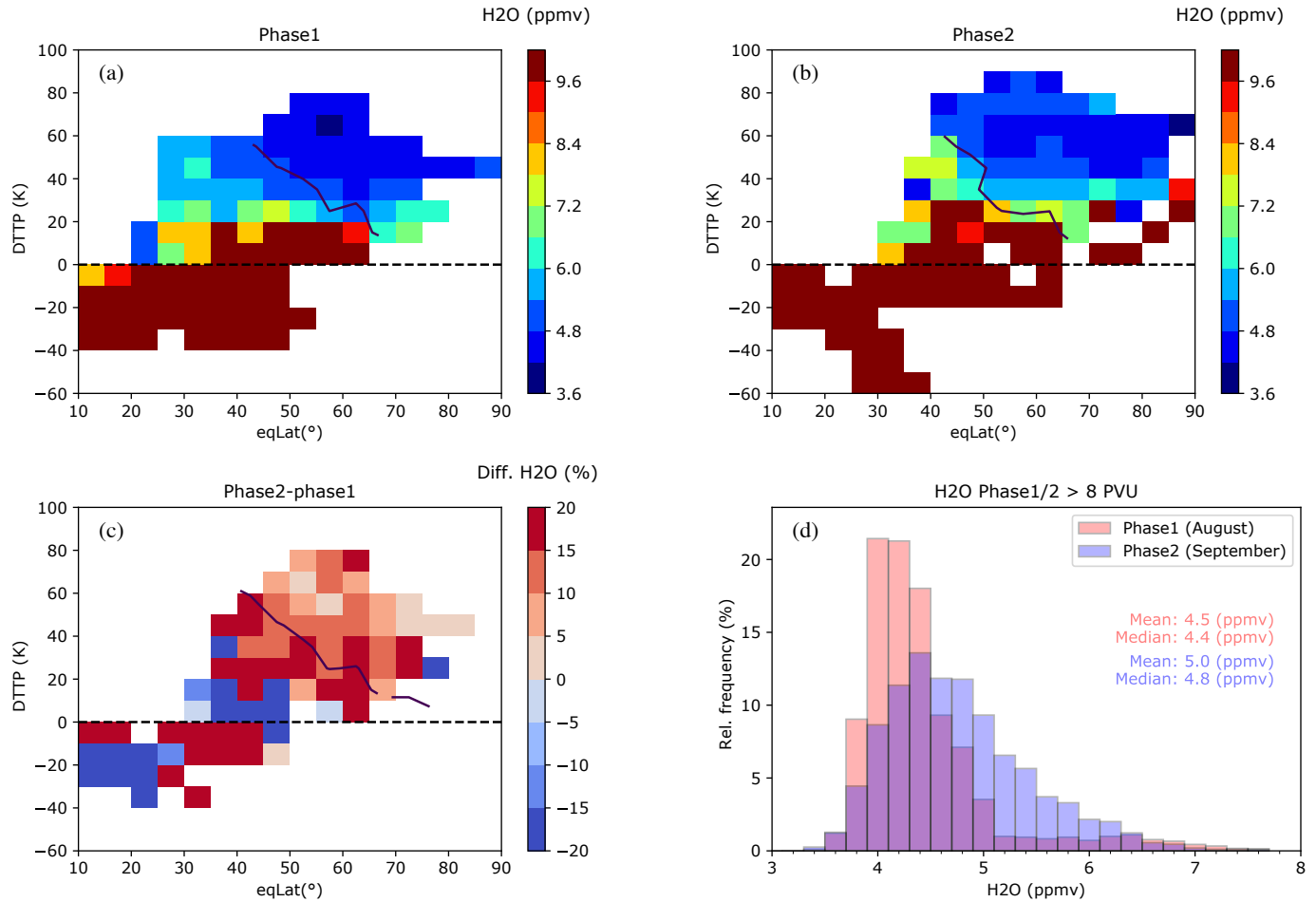

Figure 2. Mean distribution of $\mathrm{H}_{2} \mathrm{O}$ as a function of equivalent latitude and distance to thermal tropopause (DTTP) in potential temperature units: (a) phase 1 and (b) phase 2. (c) Relative differences of $\mathrm{H}_{2} \mathrm{O}$ between phase 2 and phase 1. The dashed/solid black lines represent the thermal tropopause and the 8 PVU isoline, respectively. (d) Frequency distribution of $\mathrm{H}_{2} \mathrm{O}$ for the lower stratosphere (PV $>8 \mathrm{PVU}$ ) for phase 1 (red) and phase 2 (blue). The mean and median values of each distribution are given in red and blue, respectively.
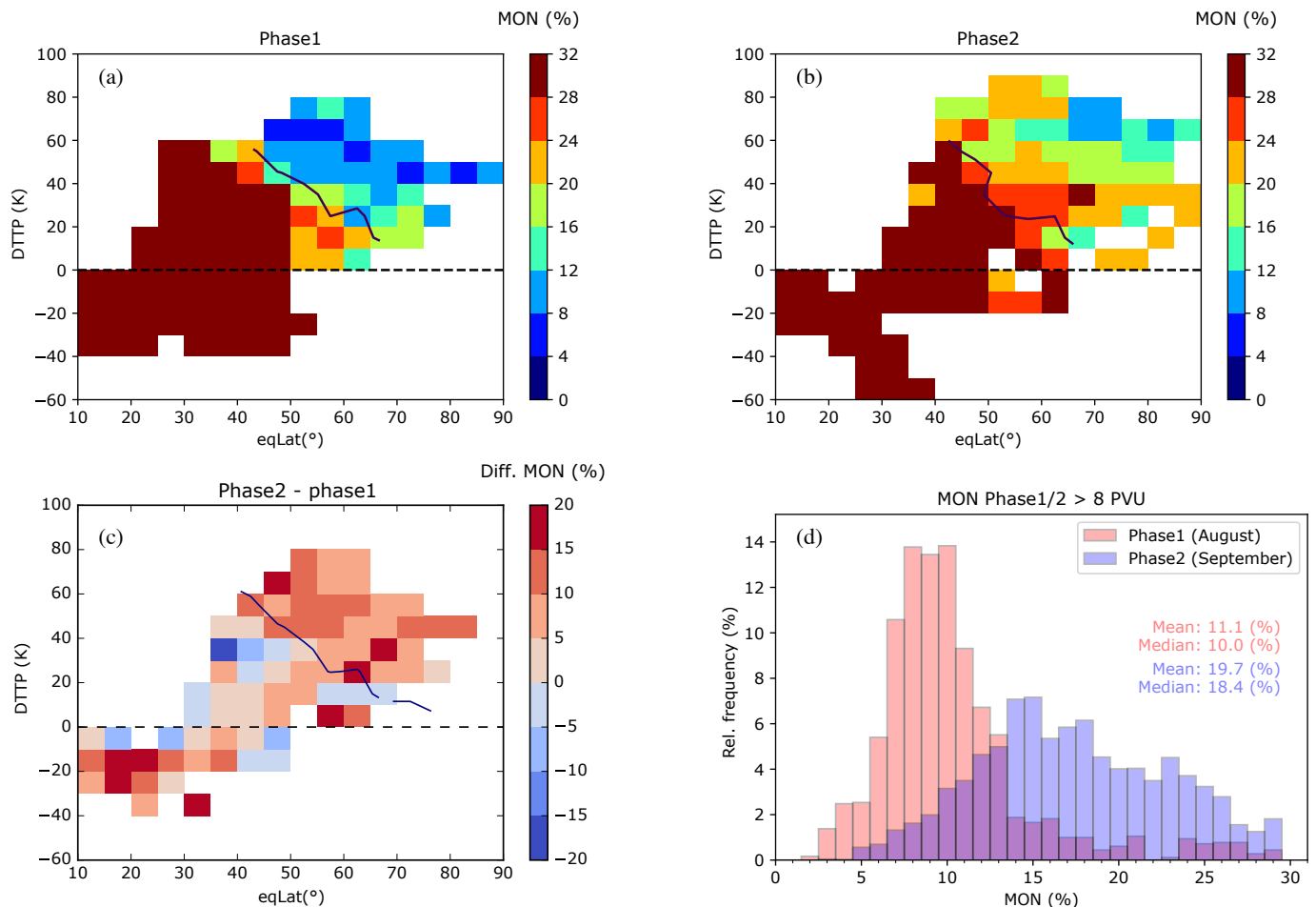

Figure 3. Same as Fig. 2 but for the simulated Asian monsoon surface tracer MON. 
vapor mixing ratios. The difference in the mean water vapor mixing ratio between the two phases indicates a statistically significant (Mann-Whitney U test with $p$ value $<10^{-100}$ ) moistening of the Ex-LS of about 0.5 ppmv within a time period of less than a month. This finding is in accordance with CLaMS model simulations and MLS satellite measurements which show a total increase of mean water vapor mixing ratio in the northern Ex-LS of $1.5 \mathrm{ppmv}(1.0 \mathrm{ppmv})$ at $380 \mathrm{~K}$ $(400 \mathrm{~K})$ in the time period from May to November due to the transport of air masses originating from source regions in Asia (see Fig. 15 in Vogel et al., 2016). The gradient of this increase was found to be at its strongest between the end of August and the end of September, which is the result of a pronounced eddy-shedding event on 20 September 2012 (Vogel et al., 2014, 2016). This strong increase perfectly matches the separation of the two phases and is in agreement with the increase observed in this study here. In addition to the measured increase in mean water vapor of $0.5 \mathrm{ppmv}$, a mean increase of $20 \mathrm{ppbv}$ methane is observed in the same time period (see Fig. 4).

\subsection{Tracer of air mass origin}

Our simulations of corresponding artificial air mass origin tracers (Fig. 3a and b) indicate that the moistening observed during phase 2 is the result of increased air mass contribution from the Asian monsoon region. MON increased by about 20 to $100 \%$ from phase 1 to phase 2 above the 8 PVU level (see Fig. 3c). The increase of MON in this altitude range is correlated with the observed increase in water vapor between the phases. The frequency distributions in Fig. 3d reveal the clear shift of MON to higher values, where the mean values show an increase of $8.6 \%$ from phase 1 to phase 2 . In particular, there is only a slight increase in surface tracers $(\sim 1 \%)$ from other locations (residual surface without the monsoon region, MON) in the same time period. Therefore, the moistening of 0.5 ppmv can be linked to the $8.6 \%$ increase of MON.

\subsection{Water vapor-methane correlation}

The correlation of observed water vapor with observed methane provides further evidence for the large air mass contribution of the Asian monsoon region. Methane's main source is at the Earth's surface and thus has the highest concentrations in the troposphere. In the stratosphere, the methane mixing ratio decreases with altitude due to oxidization. Methane concentrations are especially high in regions with large industrial activity or natural out-gassing from wetlands, such as rice cultivation in India/southeast Asia (Park et al., 2004; Xiong et al., 2009). Due to the high emissions on the ground, strongly enhanced mixing ratios of methane are found in the AMA compared to the free troposphere, as shown by the CARIBIC measurements (Schuck et al., 2010; Patra et al., 2011; Baker et al., 2012). Thus, methane is suitable as a monsoon-specific tropospheric tracer, in par-

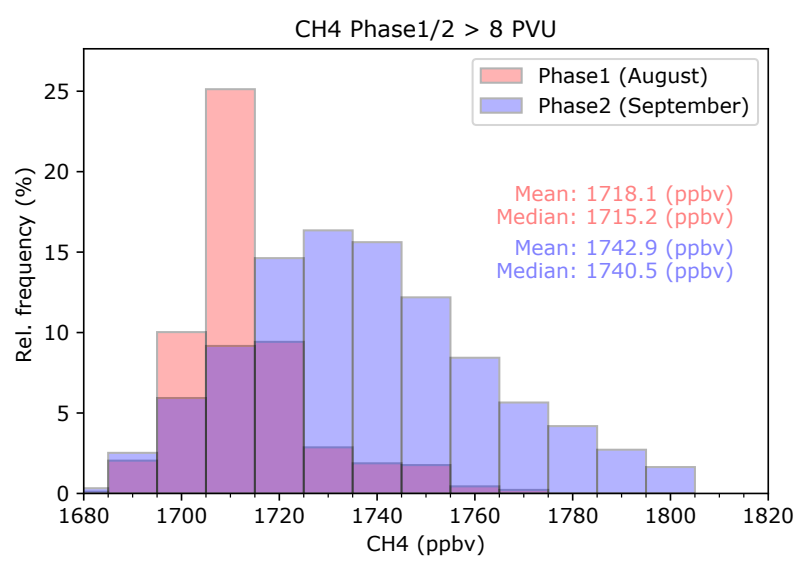

Figure 4. Frequency distribution of $\mathrm{CH}_{4}$ for the lower stratosphere (PV > 8 PVU) for phase 1 (red) and phase 2 (blue). The mean and median values of each distribution are given in red and blue, respectively.

ticular for the Asian monsoon regions. The difference in the methane distribution between the phases is visible in Fig. 4. The frequency distributions look very similar to the ones found for water vapor and MON (Sect. 3.1 and 3.2) and reveal a mean increase of $24 \mathrm{ppbv}$ methane between the phases. This provides further support for combining water vapor and methane measurements together with the artificial origin tracer MON.

Figure 5 shows the correlations of measured water vapor and methane mixing ratios in the lower stratosphere (PV > 8 PVU) for both phases. The core region (black contour) of the scatter plot encompasses $75 \%$ of the data points of the underlying frequency distribution and ranges from around 3.8 to $5.1 \mathrm{ppmv}$ in water vapor and from 1700 to 1730 ppbv in methane. The correlation in phase 1 is compact with nearly no significant enhancement in methane and water vapor compared to the water vapor background mixing ratio of 5 ppmv in the lower stratosphere (Zahn et al., 2014). The amount of MON is relatively low with values around $12 \%$ in the core region. Only a few measurements (around $10 \%$ of the data) with high MON values of up to $30 \%$ are found, showing the highest water vapor and methane values in phase 1. This indicates the moistening of the Ex-LS from the earlier phase of the monsoon before the end of August. In contrast, the correlation in phase 2 is dominated by measurements with higher methane and water vapor mixing ratios. The core region of the data ranges from 1700 to $1790 \mathrm{ppbv}$ in methane and 3.7 to $6.2 \mathrm{ppmv}$ in water vapor. The amount of MON in phase 2 is $30 \%$ and thus significantly higher compared to phase 1 . The water vapor and methane mixing ratio is statistically correlated with the MON tracer. In fact, the slope of the correlation is tilted towards higher methane mixing ratios in phase 2, which confirms the influence of methane-rich tropospheric air masses from the Asian monsoon region in the Ex-LS. The associated correlation coefficients for water 

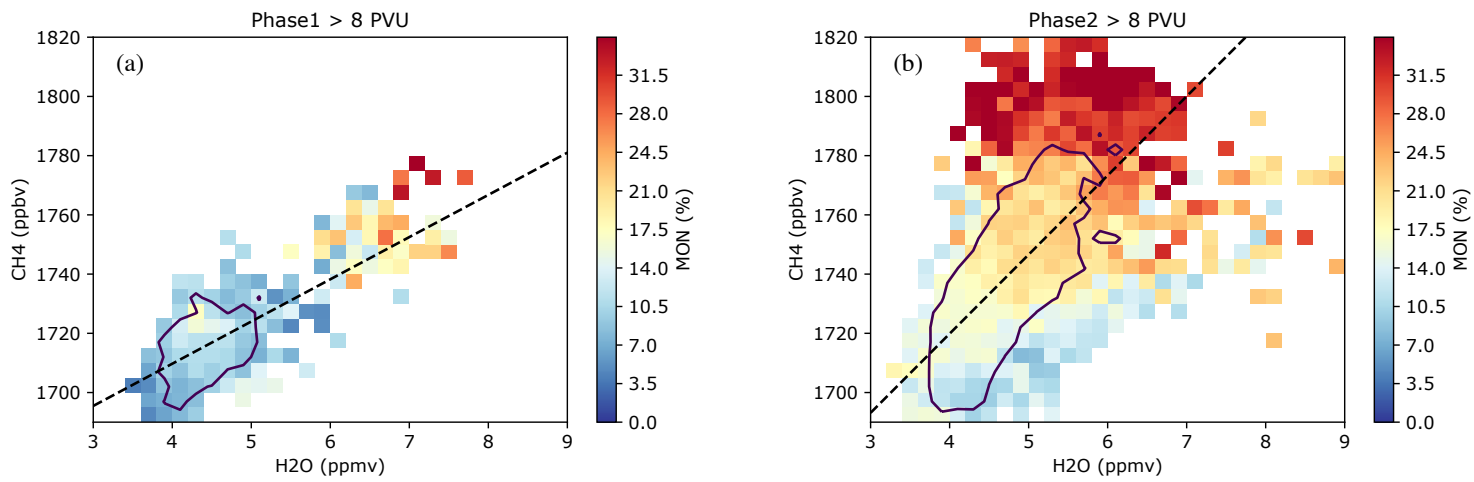

Figure 5. Correlation of water vapor and methane for PV $>8$ PVU, color-coded by the Asian monsoon surface tracer MON: (a) for phase 1 (August) and (b) for phase 2 (September). The solid black line marks the core region, which encompasses $75 \%$ of the data. The black dashed line represents a robust linear regression fitting curve (Theil-Sen regression).

vapor and methane are 0.79 and 0.67 for phase 1 and phase 2 , respectively. The correlation coefficients for the measured water vapor and modeled $\mathrm{MON}$ tracer are 0.27 in phase 1 and 0.40 in phase 2 , whilst for methane and MON tracer they are 0.41 for phase 1 and 0.63 for phase 2. All correlation coefficients (calculated according to Pearson) are highly significant with $p$ values of nearly zero $\left(<10^{-18}\right)$, thus rejecting the null hypothesis of an uncorrelated data set. In fact, the correlation for water vapor and methane is clearly higher compared to the correlation with the MON tracer, which corroborates the consistency between the in situ measurements. It also shows the limitations of CLaMS at reproducing every small-scale feature in the measurements. However, the correlation for the model-based tracer and the measurements is still quite satisfactory and strongly supports the hypothesis that the increase in water vapor is correlated to the air mass affected by the AMA.

In addition, methane shows a stronger correlation to MON due to its long lifetime of around 9 years in the troposphere and even longer lifetime in the lower stratosphere (Wuebbles and Hayhoe, 2002). It also reacts similarly to the ideal model tracer MON. In contrast, water vapor has a very short lifetime of about 9 days (Hartmann, 2015) due to its strong temperature dependency. Therefore, we can expect reduced variability of water vapor in comparison to methane and thus better correlation of methane with the MON tracer. This provides the basis for showing the connection of measured water vapor mixing ratios to their air mass temperature history in the next section.

\subsection{Lagrangian cold point from backward trajectories}

The amount of water vapor transported from the troposphere into the stratosphere is strongly coupled with the LCP, where typically the air masses are dehydrated close to the saturation mixing ratio by ice crystal formation and subsequent sedimentation (e.g., Schoeberl and Dessler, 2011). Thus, the amount of water vapor in these air masses is nearly preserved after passing the LCP in the tropical, sub-tropical, and midlatitude stratosphere. The geographic location of the LCP along the backward trajectory marks the location of these set points on the water vapor mixing ratio.

Vogel et al. (2016) showed that the eddy shedding and in-mixing of tropospheric air masses can occur at potential temperatures of around $380 \mathrm{~K}$ directly between double tropopause features, passing through the transport barrier at the climatological jet core. However, the locations of LCPs in the case of eddy shedding events do not implicitly coincide with the point of in-mixing into the Ex-LS (Schoeberl and Dessler, 2011; Vogel et al., 2016). In this case, the locations of LCPs are typically at the top of the upwelling in the AMA region, whereas in-mixing into the Ex-LS can be found at locations where Rossby wave breaking occurs eastwards or westwards of the AMA along the subtropical jet.

In the following, all backward trajectories for air parcels with PV $>8$ PVU according to Sect. 3.1 are considered, i.e., 2909 out of $11333(25.6 \%)$ trajectories for phase 1 and 7301 out of 14673 (49.8\%) trajectories for phase 2. The LCPs (see Fig. $6 \mathrm{a}$ and $\mathrm{b}$ ) are mostly located in the subtropics with equivalent latitudes ranging from 0 to $50^{\circ} \mathrm{N}$. They cluster meridionally above India/China/southeast Asia, North America, and western/northern Africa in both phases. Interestingly, all these regions can be assigned to respective monsoon systems over Asia, America, and Africa. In phase 1, only 158 out of 2909 (5.4\%) trajectories with PV > 8 PVU are classified as tropospheric with the LCP criteria above; i.e., more trajectories are entirely in the stratosphere. Furthermore, phase 2 reveals more frequent LCP occurrence with 846 out of 7301 $(11.6 \%)$ trajectories with $\mathrm{PV}>8 \mathrm{PVU}$ in these regions. In addition, phase 2 also shows a clear increase of LCPs in the region of India/China/southeast Asia compared to phase 1. This is further confirmed by the relative difference between phase 2 and phase 1, normalized to all trajectories (tropospheric and stratospheric; see Fig. 6c). The signal of the two other monsoon circulations, i.e., the American monsoon and 

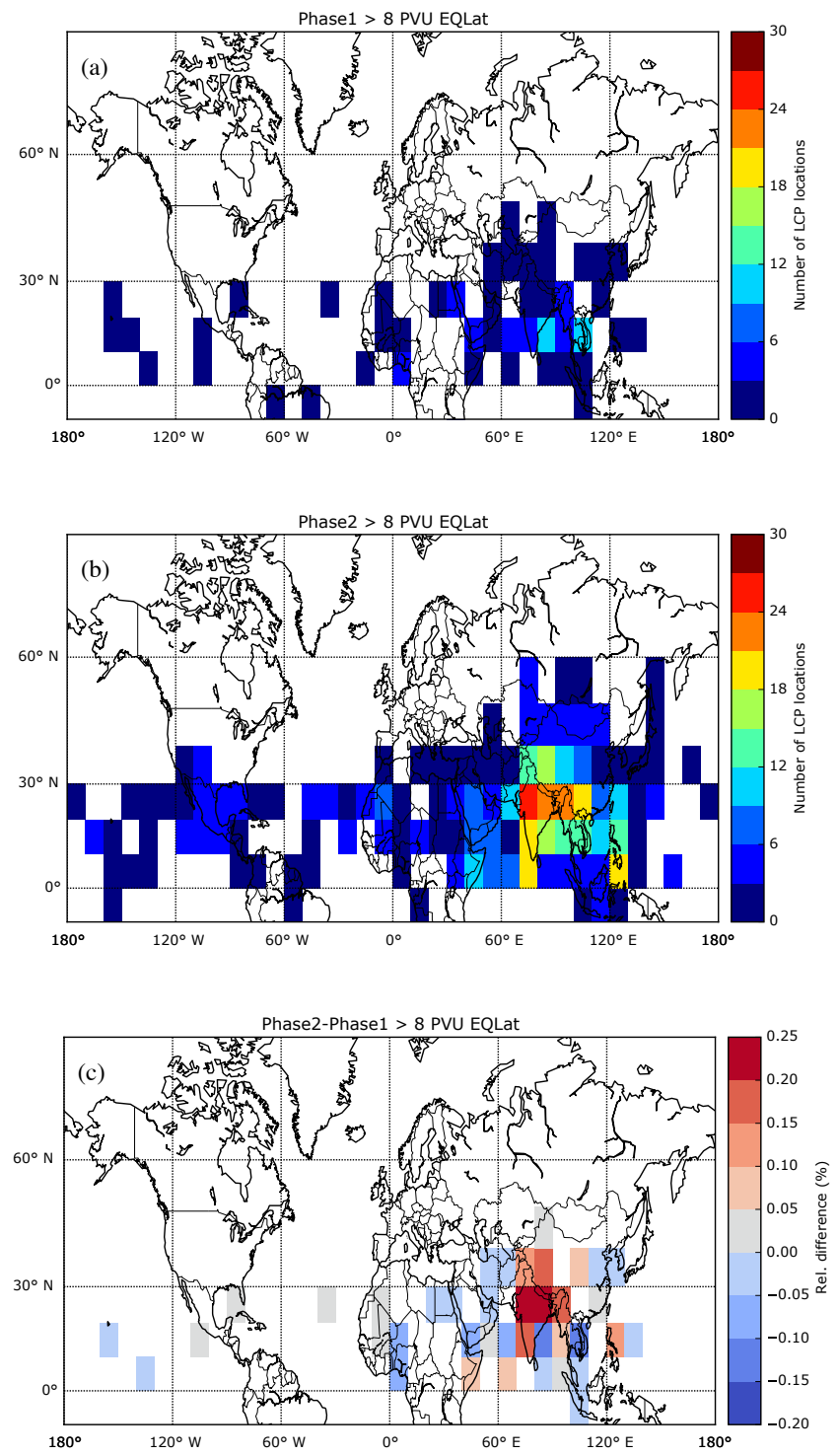

Figure 6. Location of Lagrangian cold point (LCP) binned by longitude and latitude. LCP locations for phase 1 and phase 2 are shown in (a) and (b), respectively. The relative difference normalized to the total number of trajectories is shown in (c).

the African monsoon, disappears in this analysis. The dominant appearance of LCPs in the Asian monsoon region is evident. Therefore, the Asian monsoon has the most frequent LCP occurrence, the largest extent, and thus the largest impact on stratospheric water vapor enhancements in the observed time period.

The selection criterion for trajectories described in Sect. 2.4 can be used to quantify the amount of trajectories which remained in the stratosphere for at least 50 days (stratospheric origin) or passed the LCP from the troposphere into the stratosphere (tropospheric origin), as shown in Fig. 7. In phase 1, the fraction of flight path back trajecto-

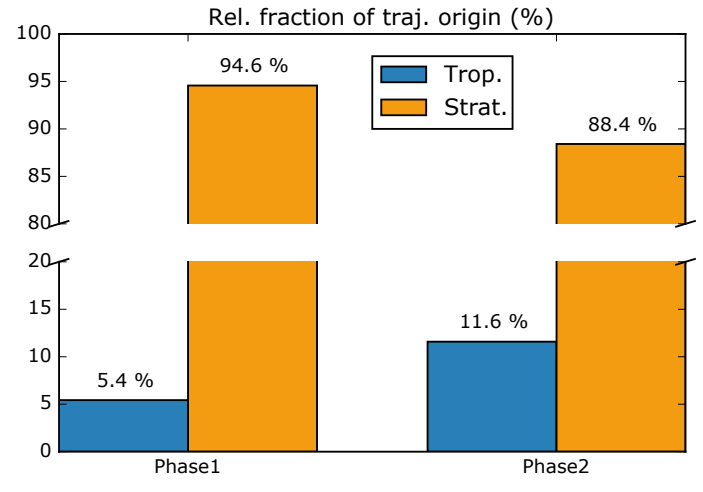

Figure 7. Fraction of trajectories with tropospheric (blue) or stratospheric (orange) origins for each phase.

ries with tropospheric origin (p1t) is $5.4 \%$ (94.6\% stratospheric, p1s), while in phase $2,11.6 \%$ (p2t) had a tropospheric origin ( $88.4 \%$ stratospheric, p2s). The larger fraction of tropospheric origin trajectories corroborates the existence of stronger troposphere-to-stratosphere exchange contributing to phase 2 . The increase in mean water vapor from phase 1 (4.5 ppmv) to phase $2(5.0 \mathrm{ppmv})$ by the Asian monsoon trajectories can be calculated with a system of linear equations:

$$
\begin{aligned}
& \left(\begin{array}{ll}
\mathrm{p} 1 \mathrm{~s} & \mathrm{p} 1 \mathrm{t} \\
\mathrm{p} 2 \mathrm{~s} & \mathrm{p} 2 \mathrm{t}
\end{array}\right)\left(\begin{array}{l}
\mathrm{wv}_{1} \\
\mathrm{wv}_{2}
\end{array}\right)=\left(\begin{array}{l}
4.5 \mathrm{ppmv} \\
5.0 \mathrm{ppmv}
\end{array}\right) \\
& \Rightarrow \mathrm{wv}_{1}=4.1 \mathrm{ppmv}, \mathrm{wv}_{2}=11.9 \mathrm{ppmv} .
\end{aligned}
$$

Here, $w_{1}$ denotes the water vapor background mixing ratio and $\mathrm{wv}_{2}$ the water vapor contribution from the monsoon trajectories. From this simple calculation, it can be concluded that the observed increase of $0.5 \mathrm{ppmv}$ in the mean water vapor mixing ratio between the phases (see Fig. 2d) can be attributed to the transport of moist tropospheric air masses with a mean water vapor mixing ratio of about 12 ppmv compared to a stratospheric background of $4.1 \mathrm{ppmv}$. These values fit quite well with the CLaMS model simulations in Vogel et al. (2016), who determined a stratospheric background of around $4 \mathrm{ppmv}$ in the same time period neglecting water vapor contributions from air masses in the Asian monsoon region.

\section{Conclusions}

The mean water vapor $(0.5 \mathrm{ppmv}, 11 \%)$ and methane (20 ppbv, $1.2 \%$ ) increases from phase 1 (August) to phase 2 (September) are correlated with an increase in Asian monsoon surface tracer (MON) by 8.6 percentage points, which corresponds to a doubling of air masses in the Ex-LS influenced by the region of the Asian monsoon, southeast Asia, and tropical Pacific Ocean. Other surface regions can be neglected as a source of the moist air masses in the stratosphere 
during northern summer. The doubling of MON is also consistent with observations of increased values of other tropospheric tracers $\left(\mathrm{N}_{2} \mathrm{O}, \mathrm{SF}_{6}, \mathrm{CO}\right)$, which were simultaneously observed (Müller et al., 2016). Our observational results also confirm the modeling study of Ploeger et al. (2013), where a simulated increase of the water vapor from 4.5 to $5.0 \mathrm{ppmv}$ in the Ex-LS corresponds to an increase of the Asian monsoon air contribution of about $10 \%$. Our observed increase in water vapor is also in accordance with the study of Vogel et al. (2016), who found that over the entire monsoon time period from June to October 2012, $1.5 \mathrm{ppmv} / 1.0 \mathrm{ppmv}$ of the water vapor in the northern hemispheric stratosphere at $380 \mathrm{~K} / 400 \mathrm{~K}$ originates from the AMA regions including southeast Asia and the tropical Pacific Ocean. The gradient of this increase was found to be at its strongest between the end of August and the end of September, similarly to the two phases used in this study.

Moreover, the flight path back trajectories support the influence of the Asian monsoon on the Ex-LS. In phase 2, twice as many trajectories show tropospheric influence compared to phase 1. The moistening in the Ex-LS is maintained by young air masses transported from the Asian monsoon with a mean mixing ratio of about 12 ppmv. The locations of the LCPs show that the set point of water vapor mixing ratios occurs most frequently above India and southeast Asia. The crossings of the tropopause in the case of eddy-shedding events are displaced to Rossby wave-breaking regions along the subtropical jet. From these points on, air masses are transported quasi-isentropically into the Ex-LS as shown by Vogel et al. (2016).

All these measurements and model results contribute to the general understanding that the Asian monsoon influences the trace gas composition of the extratropical lower stratosphere in the Northern Hemisphere - at least for the year 2012. In particular, this study provides observational evidence of the water vapor transport from the Asian monsoon region to the northern Ex-LS. Following the study of Riese et al. (2012), a 5-10\% increase of water vapor in the Ex-LS produced a top-of-the-atmosphere radiative forcing of 100 $500 \mathrm{~mW} \mathrm{~m}^{-2}$. Depending on the residence time in the lower stratosphere, the moist and methane-rich air masses have the potential to impact surface temperatures in the Northern Hemisphere.

Data availability. The observational data used in this study can be downloaded from the HALO database (https://doi.org/10.17616/R39Q0T; HALO consortium, 2017) at https://halo-db.pa.op.dlr.de/.

Competing interests. The authors declare that they have no conflict of interest.
Acknowledgements. We would like to thank the coordinators of the two HALO missions TACTS and ESMVal, namely Andreas Engel, Harald Bönisch (University of Frankfurt), and Hans Schlager (DLR), for their efforts. Special thanks go to DLR-FX for the avionic data from the Bahamas instrument, Heini Wernli for providing tropopause information, and Jens-Uwe Grooß for CLaMS model forecasts and flight planning within the LASSO project (HALO-SPP,1294/GR,3786) supported by the German Research Foundation (DFG). We would also like to thank the Jülich Supercomputing Centre (JSC) for computing time on the supercomputer JUROPA within the VSR project JICG11. Our activities were part of the DFG's AMOS project (HALO-SPP 1294/VO 1276/5-1) and the Seventh Framework Program (FP7/2007-2013) of the European Union's StratoClim project (grant agreement no. 603557). Thanks also go to the Language Services of Forschungszentrum Jülich for linguistic revision. In addition, we gratefully acknowledge the ECMWF for their meteorological reanalysis data support. We thank the two anonymous reviewers for their careful reading of our manuscript and their helpful comments and suggestions.

The article processing charges for this open-access

publication were covered by a Research

Centre of the Helmholtz Association.

Edited by: Farahnaz Khosrawi

Reviewed by: two anonymous referees

\section{References}

Baker, A. K., Schuck, T. J., Brenninkmeijer, C. A. M., RautheSchoch, A., Slemr, F., van Velthoven, P. F. J., and Lelieveld, J.: Estimating the contribution of monsoon-related biogenic production to methane emissions from South Asia using CARIBIC observations, Geophys. Res. Lett., 39, L10813, https://doi.org/10.1029/2012GL051756, 2012.

Bian, J. C., Pan, L. L., Paulik, L., Vomel, H., Chen, H. B., and $\mathrm{Lu}, \mathrm{D}$. R.: In situ water vapor and ozone measurements in Lhasa and Kunming during the Asian summer monsoon, Geophys. Res. Lett., 39, L19808, https://doi.org/10.1029/2012GL052996, 2012.

Bönisch, H., Engel, A., Curtius, J., Birner, Th., and Hoor, P.: Quantifying transport into the lowermost stratosphere using simultaneous in-situ measurements of $\mathrm{SF}_{6}$ and $\mathrm{CO}_{2}$, Atmos. Chem. Phys., 9, 5905-5919, https://doi.org/10.5194/acp-9-5905-2009, 2009.

Dee, D. P., Uppala, S. M., Simmons, A. J., Berrisford, P., Poli, P., Kobayashi, S., Andrae, U., Balmaseda, M. A., Balsamo, G., Bauer, P., Bechtold, P., Beljaars, A. C. M., van de Berg, L., Bidlot, J., Bormann, N., Delsol, C., Dragani, R., Fuentes, M., Geer, A. J., Haimberger, L., Healy, S. B., Hersbach, H., Hólm, E. V., Isaksen, L., Kallberg, P., Koehler, M., Matricardi, M., McNally, A. P., Monge-Sanz, B. M., Morcrette, J. J., Park, B. . K., Peubey, C., de Rosnay, P., Tavolato, C., Thépaut, J. N., and Vitart, F.: The ERA-Interim reanalysis: configuration and performance of the data assimilation system, Q. J. Roy. Meteor. Soc., 137, 553-597, https://doi.org/10.1002/qj.828, 2011.

Dethof, A., O'Neill, A., Slingo, J. M., and Smit, H. G. J.: A mechanism for moistening the lower stratosphere involving the Asian summer monsoon, Q. J. Roy. Meteor. Soc., 125, 1079-1106, https://doi.org/10.1256/smsqj.55601, 1999. 
Forster, P. M. D. and Shine, K. P.: Assessing the climate impact of trends in stratospheric water vapor, Geophys. Res. Lett., 29, 1086, https://doi.org/10.1029/2001GL013909, 2002.

Gettelman, A., Hoor, P., Pan, L. L., Randel, W. J., Hegglin, M. I., and Birner, T.: The Extratropical Upper Troposphere and Lower Stratosphere, Rev. Geophys., 49, RG3003, https://doi.org/10.1029/2011RG000355, 2011.

HALO consortium: High Altitude and LOng Range database, https://doi.org/10.17616/R39Q0T, 2017.

Hartmann, D. L.: Global Physical Climatology, Newnes, 103, 2. Edn., 2015.

Hegglin, M. I., Tegtmeier, S., Anderson, J., Froidevaux, L., Fuller, R., Funke, B., Jones, A., Lingenfelser, G., Lumpe, J., Pendlebury, D., Remsberg, E., Rozanov, A., Toohey, M., Urban, J., von Clarmann, T., Walker, K. A., Wang, R., and Weigel, K.: SPARC Data Initiative: Comparison of water vapor climatologies from international satellite limb sounders, J. Geophys. Res.-Atmos., 118, 11824-11846, https://doi.org/10.1002/jgrd.50752, 2013.

Hoor, P., Fischer, H., and Lelieveld, J.: Tropical and extratropical tropospheric air in the lowermost stratosphere over Europe: A CO-based budget, Geophys. Res. Lett., 32, L07802, https://doi.org/10.1029/2004GL022018, 2005.

Hsu, C. J. and Plumb, R. A.: Nonaxisymmetric thermally driven circulations and upper-tropospheric monsoon dynamics, J. Atmos. Sci., 57, 1255-1276, https://doi.org/10.1175/15200469(2000)057<1255:NTDCAU>2.0.CO;2, 2000.

Konopka, P., Steinhorst, H. M., Grooß, J. U., Günther, G., Müller, R., Elkins, J. W., Jost, H. J., Richard, E., Schmidt, U., Toon, G., and McKenna, D. S.: Mixing and ozone loss in the 1999-2000 Arctic vortex: Simulations with the three-dimensional Chemical Lagrangian Model of the Stratosphere (CLaMS), J. Geophys. Res.-Atmos., 109, D02315, https://doi.org/10.1029/2003JD003792, 2004.

Konopka, P., Grooß, J.-U., Günther, G., Ploeger, F., Pommrich, R., Müller, R., and Livesey, N.: Annual cycle of ozone at and above the tropical tropopause: observations versus simulations with the Chemical Lagrangian Model of the Stratosphere (CLaMS), Atmos. Chem. Phys., 10, 121-132, https://doi.org/10.5194/acp-10121-2010, 2010.

Krebsbach, M., Schiller, C., Brunner, D., Günther, G., Hegglin, M. I., Mottaghy, D., Riese, M., Spelten, N., and Wernli, $\mathrm{H}$.: Seasonal cycles and variability of $\mathrm{O}_{3}$ and $\mathrm{H}_{2} \mathrm{O}$ in the UT/LMS during SPURT, Atmos. Chem. Phys., 6, 109-125, https://doi.org/10.5194/acp-6-109-2006, 2006.

Kunz, A., Sprenger, M., and Wernli, H.: Climatology of potential vorticity streamers and associated isentropic transport pathways across PV gradient barriers, J. Geophys. Res.-Atmos., 120, 3802-3821, https://doi.org/10.1002/2014JD022615, 2015.

Livesey, N. J., Read, W. G., Froidevaux, L., Lambert, A., Manney, G. L., Pumphrey, H. C., Santee, M. L., Schwartz, M. J., Wang, S., Cofield, R. E., Cuddy, D. T., Fuller, R. A., Jarnot, R. F., Jiang, J. H., Knosp, B. W., Stek, P. C., Wagner, P. A., and Wu, D. L.: EOS MLS Version 3.3 Level 2 data quality and description document, Tech. Rep. JPL D33509, Jet Propulsion Laboratory, available at: http://mls.jpl.nasa.gov (last access: 12 June 2017), 2011.

McKenna, D. S., Grooß, J. U., Günther, G., Konopka, P., Müller, R., Carver, G., and Sasano, Y.: A new Chemical Lagrangian Model of the Stratosphere (CLaMS) - 2. Formulation of chem- istry scheme and initialization, J. Geophys. Res.-Atmos., 107, 4256, https://doi.org/10.1029/2000JD000113, 2002a.

McKenna, D. S., Konopka, P., Grooß, J. U., Günther, G., Müller, R., Spang, R., Offermann, D., and Orsolini, Y.: A new Chemical Lagrangian Model of the Stratosphere (CLaMS) - 1. Formulation of advection and mixing, J. Geophys. Res.-Atmos., 107, 4309, https://doi.org/10.1029/2000JD000114, 2002b.

Meyer, J., Rolf, C., Schiller, C., Rohs, S., Spelten, N., Afchine, A., Zöger, M., Sitnikov, N., Thornberry, T. D., Rollins, A. W., Bozóki, Z., Tátrai, D., Ebert, V., Kühnreich, B., Mackrodt, P., Möhler, O., Saathoff, H., Rosenlof, K. H., and Krämer, M.: Two decades of water vapor measurements with the FISH fluorescence hygrometer: a review, Atmos. Chem. Phys., 15, 85218538, https://doi.org/10.5194/acp-15-8521-2015, 2015.

Müller, S., Hoor, P., Bozem, H., Gute, E., Vogel, B., Zahn, A., Bönisch, H., Keber, T., Krämer, M., Rolf, C., Riese, M., Schlager, H., and Engel, A.: Impact of the Asian monsoon on the extratropical lower stratosphere: trace gas observations during TACTS over Europe 2012, Atmos. Chem. Phys., 16, 10573-10589, https://doi.org/10.5194/acp-16-10573-2016, 2016.

Pan, L. L. and Munchak, L. A.: Relationship of cloud top to the tropopause and jet structure from CALIPSO data, J. Geophys. Res.-Atmos., 116, D12201, https://doi.org/10.1029/2010JD015462, 2011.

Pan, L. L., Honomichl, S. B., Kinnison, D. E., Abalos, M., Randel, W. J., Bergman, J. W., and Bian, J.: Transport of chemical tracers from the boundary layer to stratosphere associated with the dynamics of the Asian summer monsoon, J. Geophys. Res.-Atmos., 121, 14159-14174, https://doi.org/10.1002/2016JD025616, 2016.

Park, M., Randel, W. J., Kinnison, D. E., Garcia, R. R., and Choi, W.: Seasonal variation of methane, water vapor, and nitrogen oxides near the tropopause: Satellite observations and model simulations, J. Geophys. Res.-Atmos., 109, D03302, https://doi.org/10.1029/2003JD003706, 2004.

Park, M., Randel, W. J., Gettelman, A., Massie, S. T., and Jiang, J. H.: Transport above the Asian summer monsoon anticyclone inferred from Aura Microwave Limb Sounder tracers, J. Geophys. Res.-Atmos., 112, D16309, https://doi.org/10.1029/2006JD008294, 2007.

Patra, P. K., Niwa, Y., Schuck, T. J., Brenninkmeijer, C. A. M., Machida, T., Matsueda, H., and Sawa, Y.: Carbon balance of South Asia constrained by passenger aircraft $\mathrm{CO}_{2}$ measurements, Atmos. Chem. Phys., 11, 4163-4175, https://doi.org/10.5194/acp-11-4163-2011, 2011.

Ploeger, F., Günther, G., Konopka, P., Fueglistaler, S., Müller, R., Hoppe, C., Kunz, A., Spang, R., Grooß, J. U., and Riese, M.: Horizontal water vapor transport in the lower stratosphere from subtropics to high latitudes during boreal summer, J. Geophys. Res.-Atmos., 118, 8111-8127, https://doi.org/10.1002/jgrd.50636, 2013.

Ploeger, F., Gottschling, C., Griessbach, S., Grooß, J.-U., Guenther, G., Konopka, P., Müller, R., Riese, M., Stroh, F., Tao, M., Ungermann, J., Vogel, B., and von Hobe, M.: A potential vorticitybased determination of the transport barrier in the Asian summer monsoon anticyclone, Atmos. Chem. Phys., 15, 13145-13159, https://doi.org/10.5194/acp-15-13145-2015, 2015.

Pommrich, R., Müller, R., Grooß, J.-U., Konopka, P., Ploeger, F., Vogel, B., Tao, M., Hoppe, C. M., Günther, G., Spelten, 
N., Hoffmann, L., Pumphrey, H.-C., Viciani, S., D’Amato, F., Volk, C. M., Hoor, P., Schlager, H., and Riese, M.: Tropical troposphere to stratosphere transport of carbon monoxide and long-lived trace species in the Chemical Lagrangian Model of the Stratosphere (CLaMS), Geosci. Model Dev., 7, 2895-2916, https://doi.org/10.5194/gmd-7-2895-2014, 2014.

Popovic, J. M. and Plumb, R. A.: Eddy shedding from the upper-tropospheric Asian monsoon anticyclone, J. Atmos. Sci., 58, 93-104, https://doi.org/10.1175/15200469(2001)058<0093:ESFTUT>2.0.CO;2, 2001.

Randel, W. J. and Jensen, E. J.: Physical processes in the tropical tropopause layer and their roles in a changing climate, Nat. Geosci., 6, 169-176, https://doi.org/10.1038/ngeo1733, 2013.

Randel, W. J. and Park, M.: Deep convective influence on the Asian summer monsoon anticyclone and associated tracer variability observed with Atmospheric Infrared Sounder (AIRS), J. Geophys. Res.-Atmos., 111, D12314, https://doi.org/10.1029/2005JD006490, 2006.

Riese, M., Ploeger, F., Rap, A., Vogel, B., Konopka, P., Dameris, M., and Forster, P.: Impact of uncertainties in atmospheric mixing on simulated UTLS composition and related radiative effects, J. Geophys. Res.-Atmos., 117, D16305, https://doi.org/10.1029/2012JD017751, 2012.

Rolf, C., Afchine, A., Bozem, H., Buchholz, B., Ebert, V., Guggenmoser, T., Hoor, P., Konopka, P., Kretschmer, E., Müller, S., Schlager, H., Spelten, N., Suminska-Ebersoldt, O., Ungermann, J., Zahn, A., and Krämer, M.: Transport of Antarctic stratospheric strongly dehydrated air into the troposphere observed during the HALO-ESMVal campaign 2012, Atmos. Chem. Phys., 15, 9143-9158, https://doi.org/10.5194/acp-159143-2015, 2015.

Santee, M. L., Manney, G. L., Livesey, N. J., Schwartz, M. J., Neu, J. L., and Read, W. G.: A comprehensive overview of the climatological composition of the Asian summer monsoon anticyclone based on 10 years of Aura Microwave Limb Sounder measurements, J. Geophys. Res.-Atmos., 122, 54915514, https://doi.org/10.1002/2016JD026408, 2017.

Schoeberl, M. R. and Dessler, A. E.: Dehydration of the stratosphere, Atmos. Chem. Phys., 11, 8433-8446, https://doi.org/10.5194/acp-11-8433-2011, 2011.

Schuck, T. J., Brenninkmeijer, C. A. M., Baker, A. K., Slemr, F., von Velthoven, P. F. J., and Zahn, A.: Greenhouse gas relationships in the Indian summer monsoon plume measured by the CARIBIC passenger aircraft, Atmos. Chem. Phys., 10, 39653984, https://doi.org/10.5194/acp-10-3965-2010, 2010.

Solomon, S., Rosenlof, K. H., Portmann, R. W., Daniel, J. S., Davis, S. M., Sanford, T. J., and Plattner, G. K.: Contributions of Stratospheric Water Vapor to Decadal Changes in the Rate of Global Warming, Science, 327, 1219-1223, https://doi.org/10.1126/science.1182488, 2010.
Uma, K. N., Das, S. K., and Das, S. S.: A climatological perspective of water vapor at the UTLS region over different global monsoon regions: observations inferred from the Aura-MLS and reanalysis data, Clim. Dynam., 43, 407-420, https://doi.org/10.1007/s00382-014-2085-9, 2014.

Ungermann, J., Ern, M., Kaufmann, M., Müller, R., Spang, R., Ploeger, F., Vogel, B., and Riese, M.: Observations of PAN and its confinement in the Asian summer monsoon anticyclone in high spatial resolution, Atmos. Chem. Phys., 16, 8389-8403, https://doi.org/10.5194/acp-16-8389-2016, 2016.

Vogel, B., Günther, G., Müller, R., Grooß, J.-U., Hoor, P., Krämer, M., Müller, S., Zahn, A., and Riese, M.: Fast transport from Southeast Asia boundary layer sources to northern Europe: rapid uplift in typhoons and eastward eddy shedding of the Asian monsoon anticyclone, Atmos. Chem. Phys., 14, 12745-12762, https://doi.org/10.5194/acp-14-12745-2014, 2014.

Vogel, B., Günther, G., Müller, R., Grooß, J.-U., and Riese, M.: Impact of different Asian source regions on the composition of the Asian monsoon anticyclone and of the extratropical lowermost stratosphere, Atmos. Chem. Phys., 15, 13699-13716, https://doi.org/10.5194/acp-15-13699-2015, 2015.

Vogel, B., Günther, G., Müller, R., Grooß, J.-U., Afchine, A., Bozem, H., Hoor, P., Krämer, M., Müller, S., Riese, M., Rolf, C., Spelten, N., Stiller, G. P., Ungermann, J., and Zahn, A.: Longrange transport pathways of tropospheric source gases originating in Asia into the northern lower stratosphere during the Asian monsoon season 2012, Atmos. Chem. Phys., 16, 15301-15325, https://doi.org/10.5194/acp-16-15301-2016, 2016.

Wuebbles, D. J. and Hayhoe, K.: Atmospheric methane and global change, Earth-Sci. Rev., 57, 177-210, https://doi.org/10.1016/S0012-8252(01)00062-9, 2002.

Xiong, X., Houweling, S., Wei, J., Maddy, E., Sun, F., and Barnet, C.: Methane plume over south Asia during the monsoon season: satellite observation and model simulation, Atmos. Chem. Phys., 9, 783-794, https://doi.org/10.5194/acp-9-783-2009, 2009.

Zahn, A., Christner, E., van Velthoven, P. F. J., Rauthe-Schoch, A., and Brenninkmeijer, C. A. M.: Processes controlling water vapor in the upper troposphere/lowermost stratosphere: An analysis of 8years of monthly measurements by the IAGOSCARIBIC observatory, J. Geophys. Res.-Atmos., 119, 1150511525, https://doi.org/10.1002/2014JD021687, 2014.

Zöger, M., Afchine, A., Eicke, N., Gerhards, M. T., Klein, E., McKenna, D. S., Morschel, U., Schmidt, U., Tan, V., Tuitjer, F., Woyke, T., and Schiller, C.: Fast in situ stratospheric hygrometers: A new family of balloon-borne and airborne Lyman alpha photofragment fluorescence hygrometers, J. Geophys. Res.-Atmos., 104, 1807-1816, https://doi.org/10.1029/1998JD100025, 1999. 